\title{
O MODELO ESCOLAR PAULISTANO NA REVISTA ESCOLA MUNICIPAL (1968-1985)
}

\author{
Alexandre Pianelli Godoy \\ Universidade Federal de São Paulo, Brasil.
}

$\cos 8$

\begin{abstract}
Resumo
O artigo pretende documentar um modelo escolar que foi implantado na cidade de São Paulo no processo de institucionalização do seu ensino municipal durante a ditadura militar por meio da revista Escola Municipal (1968-1985), principal veículo de divulgação e circulação desse modelo. $\mathrm{Na}$ primeira parte aborda o debate teórico e metodológico de modo a configurar um modelo escolar paulistano na transição entre uma sociedade disciplinar e uma sociedade de controle. A segunda parte procura desvendar os caminhos da produção e circulação da materialidade do impresso em suas diferentes fases, mostrando as características e fragilidades de tal modelo. A última parte procura estabelecer as relações entre o modelo escolar paulistano e o tipo de leitor desejado pela publicação e nas políticas municipais de educação do período.

Palavras-chave: impresso escolar, modelo escolar, São Paulo, ditadura militar, sociedades disciplinares e de controle.
\end{abstract}

\section{THE SÃO PAULO SCHOOL MODEL BY MUNICIPAL SCHOOL MAGAZINE (1968-1985)}

\begin{abstract}
The article aims to document a school model which was implemented in the city of Sao Paulo in the process of institutionalization of their Municipal teaching during the military dictatorship through the magazine Municipal School (1968-1985), the main vehicle for dissemination and circulation of this model. The first part discusses the theoretical and methodological debates in order to set up a "São Paulo school model" in the transition between a disciplinary society and a society of control. The second part seeks to uncover the ways of production and circulation of the materiality of print in its various stages, showing the features and weaknesses of a such model. The last part seeks to establish relations between the São Paulo school model and the publication desirable readers type and the municipal education policies of the period.

Key-words: printed school, school model, São Paulo, military dictatorship, disciplinary societies and control.
\end{abstract}




\section{EL MODELO ESCOLAR PAULISTANO EN LA REVISTA \\ ESCOLA MUNICIPAL (1968-1985)}

\section{Resumen}

El artículo pretende documentar un modelo escolar que fue implantado en la ciudad de São Paulo en el proceso de institucionalización de su enseñanza municipal durante la dictadura militar por medio de la revista Escola Municipal (1968-1985), principal vehículo de divulgación y circulación de ese modelo. En la primera parte se aborda el debate teórico y metodológico con la intención de configurar un modelo escolar paulistano en la transición entre una sociedad disciplinar y una "sociedad de control. La segunda parte pretende desvendar los caminos de la producción y circulación de la materialidad del impreso en sus diferentes fases, mostrando las características y fragilidades de tal modelo. La última parte pretende establecer las relaciones entre el "modelo escolar paulistano" y el tipo de lector deseado por la publicación y en las políticas municipales de educación del período.

Palabras-clave: impreso escolar, modelo escolar, São Paulo, dictadura militar, sociedades disciplinares y de control.

\section{LE MODĖLE SCOLAIRE DE SÃO PAULO DANS LA REVUE ÉCOLE MUNICIPALE (1968-1985)}

\section{Résume}

L'article prétend documenter un modèle scolaire qui a été implanté dans la ville de São Paulo au processus d'institutionnalisation de son enseignement municipal durant la dictature militaire par la revue École Municipale (1968-1985), principal véhicule de divulgation et circulation de ce modèle. À la première partie, on aborde le débat théorique et méthodologique de manière à configurer un modèle scolaire de São Paulo à la transition entre une société disciplinaire à une société de contrôle. La deuxième partie essayer dévoiler les chemins de la production et circulation de la materialité des publications dans ces différentes fases, en montrant les caractéristiques et fragilités de tel type de modèle. La dernière partie essayer établiser les relations entre le modèle scolaire de São Paulo et le type de lecteur souhaité par la publication et dans les politiques municipaux de l'éducation de ce période.

Mots-clé: publication scolaire, modèle scolaire, São Paulo, dictature militaire, société disciplinaires et de contrôle. 


\section{Em busca de um modelo escolar}

- ste artigo aborda a revista Escola Municipal, periódico que circulou durante a ditadura militar nas escolas da cidade de São Paulo, e faz parte de uma pesquisa mais ampla sobre a história de oito escolas municipais que foram renomeadas ou denominadas com nomes de patronos militares.

A pesquisa Em nome da ordem: as escolas municipais de primeiro grau na cidade de São Paulo no período da ditadura militar (1964-1985), busca compreender qual o significado histórico da atribuição desses nomes às escolas e suas relações com a arquitetura escolar, as disciplinas, os currículos escolares (de Língua Portuguesa, História, Geografia, Estudos Sociais, Educação Moral e Cívica e OSPB) e as comemorações cívicas no processo de institucionalização e consolidação de um sistema público de ensino municipal. ${ }^{1}$ Dentre o material pesquisado, a revista se constitui numa parte importante para documentar como o governo municipal via e queria ser visto na organização do seu sistema de ensino

De fato, até o final dos anos 1960, o Estado e o Município de São Paulo custaram a se autonomizar em matéria educativa. Oficialmente o ensino municipal de São Paulo foi criado em 1956, todavia, desde 1951 havia propostas para que a cidade assumisse e construísse a sua própria rede de ensino. Isso permaneceu enquanto vigoraram os convênios escolares, pelos quais o município construía escolas e o Estado as geria na contratação de pessoal técnico, administrativo e docente. Mesmo após o fim dos convênios escolares em 1959, o município de São Paulo apenas começava a firmar seus próprios quadros e a construir suas salas de aula em galpões de madeira improvisados e, aqui e acolá, os primeiros prédios de alvenaria em bairros pobres e periféricos (Abreu, 2007).

Enquanto o Estado de São Paulo já contava com uma rede de ensino e com dispositivos de disseminação de sua unidade político-pedagógica por meio de periódicos educacionais datados do início do século 20 , o Município viveu nesta afasia discursiva até 1968. Não havia ainda uma revista, jornal ou caderno que fizesse circular os saberes pedagógicos, as diretrizes administrativas ou uma concepção de educação que subsidiasse a teoria e a prática àqueles que começavam a construir um ensino público paulistano. Somente o Diário Oficial do Município institucionalizava decretos, leis e pareceres. Não existia um modelo a ser seguido, tampouco a ser transgredido.

Os estudos empreendidos por Marta Maria Chagas de Carvalho nos fornecem uma boa chave de leitura para compreender as diferenças entre o modelo escolar paulista altamente regionalizado, que foi hegemônico até meados dos anos 1920, sua substituição

\footnotetext{
${ }^{1}$ A pesquisa está sediada na Pontifícia Universidade Católica de São Paulo e tem como coordenadora geral a prof. dra. Helenice Ciampi. Conta a atuação do prof. dr. Alexandre Pianelli Godoy (Unifesp /EFLCH/Departamento de História, campus Guarulhos) e com dois estudantes de iniciação científica com bolsa do CNPq. É um projeto interinstitucional entre PUCSP e Unifesp que objetiva publicar seus resultados a partir da finalização do projeto em julho de 2012. Já foram apresentados três relatórios de pesquisa e parte do que aqui foi publicado é fruto dessas reflexões. Ademais, este artigo também é o resultado das discussões do grupo de pesquisa História cultural da escola e dos saberes pedagógicos: impressos e modelos culturais, registrado no CNPq, sediado na Unifesp/EFLCH, campus Guarulhos, e coordenado pela prof. dra. Maria Rita de Almeida Toledo, do Departamento de História. Dele também participam pesquisadores e estudantes dos cursos de Pedagogia e História da Unifesp e de outras instituições de ensino do Estado de São Paulo.
} 
por um modelo mais internacionalizado, representado pela Pedagogia da Escola Nova e que perdurou até os anos 1970, e o que estou a designar de modelo escolar paulistano do Município, que começou a ser construído no final da década de 1960. Vale estar atento para a noção de modelo como ferramenta de análise e a concepção de modelo escolar paulista como conceito heurístico criado pela autora para compreender suas especificidades:

Como ferramenta de descrição e análise, um modelo exige que os elementos que o compõem sejam situados na rede de relações que o constituem. No caso em questão, falar em "modelo escolar" remete à pluralidade e à historicidade dos dispositivos científicos, religiosos, políticos e pedagógicos, em cuja intersecção se produziu, na modernidade, uma modalidade escolar de educação. A adjetivação "paulista" remete às iniciativas republicanas de institucionalização escolar no Estado de São Paulo, nas primeiras décadas do regime. Pensada nessa tripla dimensão é que a concepção de modelo escolar paulista é ferramenta fértil de descrição e análise das práticas e dos dispositivos de institucionalização da escola em São Paulo, nas primeiras décadas da República. [...] Importa-me, portanto, falar aqui, de modelos pedagógicos concorrentes em circulação em São Paulo, nas cinco primeiras décadas republicanas. Esses modelos pedagógicos põem em cena representações contrastantes da escola e das práticas de ensino e aprendizagem. Na proliferação dos discursos que articulam tais representações, dois modos distintos de normatização das práticas escolares buscaram legitimar-se como saber pedagógico de tipo novo, moderno, experimental e científico, produzindo estratégias concorrentes de configuração do campo dos saberes representados como necessários à prática docente. [...] no campo normativo da pedagogia moderna, essa pedagogia prática que animou as iniciativas de institucionalização da escola no Estado de São Paulo a partir do século 19, a pedagogia é arte de ensinar. Estruturando-se no primado da visibilidade, essa pedagogia propõe-se como arte cujo segredo é a boa imitação dos modelos. Diferentemente, a pedagogia da Escola Nova que se difunde no país a partir de meados da década de 1920 pretende subsidiar a prática docente como um repertório de saberes autorizados, propostos como seus fundamentos ou instrumentos. (Carvalho, 2011, p. 188-191)

O trecho do artigo de Marta Carvalho supracitado é fruto de quase três décadas de pesquisa sobre a história da educação paulista no período republicano, constituindo-se em síntese fundamental para compreender suas permanências e mudanças. Grande parte de suas fontes de pesquisa estão baseadas na análise das formas de produção e circulação de saberes pedagógicos presentes na materialidade dos impressos escolares e educacionais e na apreensão do sentido das formas, procedimento emprestado de Michel De Certeau, que configuram esses modelos escolares.

É importante observar que a partir da interpretação de extensa gama destas publicações, a autora distingue melhor o que se constituiu o modelo escolar paulista e sua substituição por outro modelo de hegemonia:

Essa lógica de organização do impresso que fornece ao professor coisas para usar levou-me a construir um modelo de configuração material do impresso que chamei de caixa de utensílios. Convenci-me de que essa 
modalidade de impresso destinado a professores ganha inteligibilidade se é referida à concepção da pedagogia como arte de ensinar, que alimentava as iniciativas educacionais dos republicanos paulistas na década de 1890. Nessa pedagogia, como se viu, é central a noção de imitação de práticas exemplares fundada no princípio de que ensinar a ensinar é fornecer bons moldes. [...] Mas é somente a partir da segunda metade da década de 1920 que são nítidos os sinais que os saberes pedagógicos que vinham balizando as iniciativas de institucionalização do modelo escolar paulista haviam esgotado sua capacidade de normatizar as práticas escolares [...]. No novo discurso pedagógico que começa a circular no país é produzido um novo cânone a regular as práticas escolares e são as novas ciências da educação que são chamadas a dizer a verdade sobre a criança e sua educação. (Carvalho, 2011, p. 188-195)

Minha hipótese de pesquisa é baseada na esteira do que Marta Carvalho designou de modelos escolares para encontrar o que há de novo, diferente ou específico no ensino municipal por meio de sua revista Escola Municipal, sem desprezar as influências que o modelo escolar paulista e a pedagogia da Escola Nova possam ter tido na configuração de um modelo escolar paulistano para a construção do seu ensino.

Os modelos designados por Carvalho parecem calcados nas categorias tempo e temporalidade uma vez que nasceram sobre o signo da produção fabril, isto é, do crescimento urbano, da organização do Estado laico e republicano e, sobretudo, da valorização dos conhecimentos científicos como base para a organização social. Incorporam o tempo na concepção de construção dos seus edifícios baseado na visibilidade e nos bons moldes de ensino a serem seguidos, ambos feitos para perdurar e durar. O tempo da criança deveria ser levado em consideração a partir de métodos ativos de ensino e o currículo seriado possibilitaria a consecução desse objetivo. Tal é a arte de ensinar do modelo escolar paulista.

Esse modelo foi substituído ao incorporar a temporalidade ao ensino, ou melhor, a maior consciência temporal do ensino baseada na racionalização científica da educação como parâmetro de organização das escolas e, por sua vez, numa visão mais consciente do processo de ensino para uma nova formação social. Não bastava apenas introduzir métodos ativos que respeitassem o tempo da criança e um currículo seriado/linear, mas fundamentá-los com as disciplinas científicas, principalmente na Psicologia, Filosofia e Sociologia da Educação, que tornariam o ensino um modo consciente de ação pedagógica e, consequentemente, de aprendizagem e transformação social. Tal é a ciência do ensinar da Pedagogia da Escola Nova.

Não quero afirmar que a categoria tempo se separe da de espaço, uma vez que os saberes postos em circulação e sua apropriação alteram tanto os espaços da ação pedagógica quanto o tempo escolar. Todavia, as categorias tempo e temporalidade organizaram, respectivamente, a arte de ensinar do modelo escolar paulista, tempoduração, assim como a da ciência do ensinar da Pedagogia da Escola Nova, temporalidade-processo. 
Diversamente, o modelo escolar paulistano está calcado nas categorias de lugar e espaço $^{2}$ das sociedades do pós Segunda Guerra Mundial que lidam com a maior aceleração do tempo histórico e, por sua vez, com a idéia de controle dos espaços associada à de redução das distâncias. Em estudo sobre a relação entre velocidade e política de 1977, Paul Virilio fazia esse diagnóstico no auge da Guerra Fria:

Os blocos antagônicos podem muito facilmente proscrever a perspectiva das guerras bacteriológica, geodésica ou meteorológica. Na verdade, o que está em causa atualmente com os acordos sobre a limitação das armas estratégicas não é mais o explosivo e sim o vetor, o vetor de entrega nuclear ou, mais exatamente ainda, sua performance. O motivo é simples: ali onde as deflagrações do explosivo (molecular ou nuclear) contribuíram para tornar o espaço impróprio para a existência, agora são as do implosivo (veículos vetores) que reduzem a nada o tempo de agir e, politicamente, o de decidir. Se, há mais de trinta anos, o explosivo nuclear encerrava o ciclo das guerras do espaço, neste final de século, o implosivo (mais do que os territórios invadidos política e economicamente) inaugura a guerra do tempo. Em plena coexistência pacífica, sem declaração de hostilidades e mais seguramente do que qualquer tipo de conflito, a celeridade nos livra deste mundo. Precisamos nos render à evidência: hoje, a velocidade é a guerra, a última guerra. (Virilio, 1996, p. 127)

A contradição do modelo escolar paulistano residia em calcar a sua identidade na construção de um lugar próprio, mais moderno e acelerado, num tempo histórico ainda marcado por profundas desigualdades sociais que travavam o ritmo das mudanças sociais e educativas, sobretudo em uma ditadura militar. Obviamente, as escolas estaduais também participaram desse processo de transformação, todavia, o sistema estadual de ensino já havia sido institucionalizado e não nasceu sob o signo das contradições entre espaço e lugar colocadas para as sociedades mais velozes do pósguerra.

O tempo era um aliado do ensino estadual por ter construído sua história e identidade baseado em novos métodos e saberes pedagógicos desenvolvidos em uma longa tradição do pensamento educacional liberal. O espaço para tal educação deveria ter o peso e a duração de suas pretensões: uma arquitetura escolar monumental em estilo neoclássico em pontos centrais da cidade que beneficiavam as elites. Sem esta tradição, o ensino municipal tentava criar seu lugar institucional com métodos e saberes pedagógicos emprestados e em galpões de madeira improvisados, construídos nas periferias da cidade para grande parte da população que, até então, não havia tido acesso

\footnotetext{
${ }^{2}$ As categorias de lugar e espaço são distintas e definidas por Michel de Certeau (1996), autor central para esta pesquisa: "um lugar é a ordem (seja qual for) segundo a qual se distribuem elementos nas relações de coexistência. Aí se acha portanto excluída a possibilidade, para duas coisas, de ocuparem o mesmo lugar. Aí impera a lei do 'próprio': os elementos considerados se acham uns ao lado dos outros, cada um situado num lugar 'próprio' e distinto que define. Um lugar é portanto uma configuração instantânea de posições. Implica uma indicação de estabilidade. [...] Espaço é o efeito produzido pelas operações que o orientam, o circunstanciam, o temporalizam e o levam a funcionar em unidade polivalente de programas conflituais ou de proximidades contratuais. O espaço estaria para o lugar como a palavra quando falada, isto é, quando é percebida na ambiguidade de uma efetuação, mudada em um termo que depende de múltiplas convenções, colocada como o ato de um presente (ou de um tempo), e modificado pelas transformações devidas a proximidades sucessivas. Diversamente do lugar, não tem portanto nem a univocidade nem a estabilidade de um 'próprio"' (1996, p. 201-202).
} 
à escola. A ligeireza da expansão de oportunidades revelava, no entanto, uma lógica de poder ultramoderna em um contexto ainda precário, pobre e periférico.

Nos anos 1960, dentro de um contexto diferente do nosso, Gilles Deleuze denominou esta nova lógica de poder de sociedades de controle, em substituição das sociedades disciplinares, que predominaram no século 19 até a primeira metade do século 20:

É certo que entramos em sociedades de 'controle', que já não são exatamente disciplinares. Foucault é com frequência considerado como o pensador das sociedades de disciplina, e de sua técnica principal, o confinamento (não só o hospital e a prisão, mas a escola, a fábrica, a caserna). Porém, de fato, ele é um dos primeiros a dizer que as sociedades disciplinares são aquilo que estamos deixando para trás, o que já não somos. Estamos entrando nas sociedades de controle, que funcionam não mais por confinamento, mas por controle contínuo e comunicação instantânea. [...] certamente, não se deixou de falar da prisão, da escola, do hospital: essas instituições estão em crise. Mas se estão em crise, é precisamente em combates de retaguarda. O que está sendo implantado, às cegas, são novos tipos de sanções, de educação, de tratamento. Os hospitais abertos, o atendimento a domicílio, etc., já surgiram há muito tempo. Pode-se prever que a educação será cada vez menos um meio fechado, distinto do meio profissional - um outro meio fechado -, mas que os dois desaparecerão em favor de uma terrível formação permanente, de um controle contínuo se exercendo sobre o operário-aluno ou o executivo-universitário. Tentam nos fazer acreditar numa reforma da escola, quando se trata de uma liquidação. Num regime de controle nunca se termina nada. (Deleuze, 1990, p. 215-216)

Evidentemente não devemos transportar o contexto europeu e norte-americano para o brasileiro. Aqui, a diferença mais nítida é que essa política de controle havia começado para população pobre que deveria ser preparada para o mercado de trabalho como um operário-aluno tanto em períodos democráticos instáveis como em períodos autoritários conturbados (cf. Cunha, 2005; Sposito, 2002). Lá atingiu, em primeira mão, as camadas médias já transformadas em executivo-universitário em democracias consolidadas. Portanto, adquire em nossas paragens um novo sentido para o fato de que "quanto mais cresce a rapidez, mais decresce a liberdade" (Virilio, 1996, p. 130) e, portanto, favorece a formação de redes institucionais baseadas não no confinamento e na disciplina, mas na abertura, na expansão, na produtividade com vistas ao maior controle dos lugares de atuação visando $o$ seu crescimento acelerado, funcional e dinâmico e, consequentemente, diminuindo os espaços de ação ${ }^{3}$ da população mais pobre da cidade que experimentava uma frágil promessa de mobilidade social.

\footnotetext{
${ }^{3}$ Gilles Deleuze enfatiza em outro artigo da mesma coletânea: "Mas as disciplinas, por sua vez, também conheceriam uma crise, em favor de novas forças que se instalaram lentamente e que se precipitaram depois da Segunda Guerra mundial: sociedades disciplinares é o que já não éramos mais, o que deixávamos de ser. [...] Encontramo-nos numa crise generalizada de todos os meios de confinamento, prisão, hospital, fábrica, escola, família. A família é um 'interior', em crise como qualquer outro interior, escolar, profissional, etc. Os ministros competentes não param de anunciar reformas supostamente necessárias. Reformar a escola, reformar a indústria, o hospital, o exército, a prisão; mas todos sabem que essas instituições estão condenadas, num prazo mais ou menos longo. Trata-se apenas de gerir sua agonia e ocupar as pessoas, até a instalação das novas forças que se anunciam. São as sociedades de controle que estão substituindo as sociedades disciplinares. 'Controle' é o nome que Burroughs propõe para designar o novo monstro, e que Foucault reconhece como nosso futuro próximo. Paul Virilio também analisa sem parar as formas ultrarrápidas de controle ao ar livre, que substituem as antigas disciplinas que operavam na duração de um sistema fechado" (1990, p. 219-220).
} 
Não se trata apenas de eleger espaço e lugar como categorias que articulam esse modelo escolar em função da arquitetura e do espaço escolar, mas porque tais aspectos tornaram-se mais centrais na definição das políticas municipais de ensino no período do que uma atenção para as concepções educativas e pedagógicas que regiam fortemente os modelos anteriores. Neste sentido, o modelo escolar paulistano nasce sob o signo da gestão para o ensinar, ou seja, uma visão mais administrativa do ensino e menos ancorada nos métodos e nos saberes pedagógicos. Estes, inclusive, poderiam ser selecionados de diferentes matrizes desde que mantivessem o funcionamento das escolas e permitissem um controle do lugar de ensino.

Por isso, o processo que pretendo documentar de construção da rede de ensino municipal foi mais complexo e menos visível: a passagem de uma sociedade disciplinar, baseada no domínio do tempo de ensino e que ainda não havia se extinguido, para uma sociedade de controle, baseada na gestão do lugar de ensino, que começava a surgir nos anos 1960, mas que ainda não estava consolidada tanto do ponto de vista social quanto educacional no Brasil daqueles tempos. O ensino municipal surge, se desenvolve e se consolida neste entremeio em que as categorias de lugar e espaço foram articuladoras centrais do seu modelo escolar. A revista Escola Municipal é o ponto de partida para compreender este modelo escolar da gestão para o ensinar.

A revista Escola Municipal, em seu número 3, de 1971, em edição comemorativa dos 15 anos do ensino municipal primário de São Paulo, documentou com exaustão os feitos educacionais no município, entre eles as atividades da Comissão de Construções Escolares:

Oriunda do antigo convênio escolar celebrado entre Estado e Prefeitura, a Comissão de Construções Escolares - PREF. C. E., é o órgão responsável pelo planejamento e projeto das construções de prédios escolares e parques infantis, além de se incumbir da conservação e da reforma de todos os próprios municipais destinados ao ensino e à recreação, além daqueles destinados ao funcionamento de unidades escolares do Ensino Primário e Médio do Estado. Nestes quinze anos de atividades do Ensino Municipal, a Comissão de Construções Escolares construiu para o ensino os seguintes prédios de alvenaria: 1956/1965.... 24 unidades; 1965/1969.... 145 unidades; $1969 / 1971 \ldots 57$ unidades; total 226 unidades. [...] No início do ensino, para retirar as classes das salas alugadas, Pref. C. E. construiu galpões de madeira. Assim nada menos que 158 galpões foram construídos. De 1956 até 1963, 24 desses galpões foram extintos, e das unidades restantes (134), foram construídos prédios de alvenaria (131), que as substituíram. $\mathrm{Na}$ área da Capital, somente 3 unidades funcionam em galpão de madeira, aguardando a conclusão de prédios de alvenaria para substituí-las. [...] A Comissão de Construções Escolares é dirigida por um Presidente, e no decorrer destes 15 anos, ocuparam esse posto os seguintes engenheiros: Jaime R. Pereira de 56 a 58; Olavo de Freitas de 58 a 60; Werther Krause de 61 a 65; Marco Aurélio Verlangieri de 65 a 66; Armando Arruda Camargo de 66 a 70; João Walter Richetti de 70 a 71. [...] Atualmente é Presidente da Comissão o Engenheiro Marcelo Amarantes Mendes. (Escola Municipal, n. 3, 1971, p. 29)

Se a data de criação oficial do ensino municipal foi em 1956, a fabricação de sua autonomia em relação ao ensino estadual foi posterior, não apenas pelo crescimento do número de escolas de alvenaria do Município mas, sobretudo, por meio da revista Escola 
Municipal (1968-1985), pela qual se tentava construir uma memória histórica (Vesentini, 1997) para o ensino municipal, ao atribuir sentidos ao passado em função daquele presente, isto é, o da criação de uma administração escolar burocratizada e racional de gestão para o ensino e, por fim, da materialização desta memória administrativa por meio da sua arquitetura escolar.

A história da materialidade do impresso também atesta que a publicação da revista Escola Municipal acompanhou/instaurou o processo de institucionalização da rede municipal, sem poupar críticas à atuação do Estado de São Paulo em matéria educativa, algo que seria constante por toda a década de 1970. No número inaugural, de 1968, no número 3 , de 1971, comemorativo aos 15 anos do ensino municipal, no número 6 , de 1976, comemorativo aos 20 anos, e no número 10, de 1981, comemorativo aos 25 anos, são comuns artigos sobre a história do ensino municipal ou dados estatísticos que visavam comprovar que o ensino municipal tinha sido mais efetivo em atender a população do que o Estado.

Os artigos e matérias reforçavam a data de 1956 como aquela que simbolizava a dificuldade de formar as primeiras turmas por meio do idealismo, heroísmo e entusiasmo das primeiras professoras nos galpões de madeira. Os anos 1960 como fase de institucionalização da rede municipal e os anos 1970 como a de pujança do sistema, principalmente com a implantação pioneira da escola de oito anos. Em todos os artigos a construção das escolas de alvenaria em substituição aos barracões de madeira parece ter sido o marco visível de sua evolução, como se pode notar na matéria sobre a Comissão de Construções Escolares citada acima.

É um discurso que pretende fundar um lugar imaginário, moderno e racional, que se repete retoricamente na revista ao longo do tempo e que busca formar a memória histórica do ensino municipal. Se, num primeiro momento, era comum apontar a precariedade da segunda metade dos nos 1950 para sustentar o progresso material e institucional da rede nos anos 1960-1970, apagando práticas docentes, saberes pedagógicos, currículos e arquitetura escolar da fase heróica, num segundo momento exalta-se a qualidade da rede e do sistema nos anos 1960 e 1970, apagando os problemas enfrentados naquele presente.

Essa dupla operação discursiva era sempre construída em oposição ao Estado de São Paulo para marcar o lugar ocupado pelo ensino municipal. Era o início dessa disputa por um lugar de memória (Nora, 1993) materializada pela publicação da revista Escola Municipal que nos permite afirmar a fabricação da autonomia do ensino municipal frente ao Estado. Vejamos alguns exemplos dessa operação histórica (Certeau, 2000). Na revista de número 1 , de 1968, pode-se ler:

Como se vê, embora o estado contasse com número ligeiramente maior de estabelecimentos de ensino na Capital, considerando-se a enorme diferença de tempo de existência entre o ensino estadual com mais de sessenta anos e o Municipal, com três, aquela diferença para mais, era, na verdade, para menos, contra o Estado. (Escola Municipal, n. 1, set., 1968, p. 10)

O artigo, assinado pela professora Tarsila Pousa Machado e pelo professor João Junqueira, é enorme para os padrões das revistas pedagógicas mais recentes, no 
entanto, mostra minuciosamente a institucionalização da rede. O título do artigo O nosso ensino municipal é relevante, marcando a idéia de posse, de lugar, de território ocupado e da memória que se procurava fundar. Já na revista de número 6, de 1976, em artigo igualmente longo, a professora Maria Aparecida Rodrigues Silva, orientadora pedagógica da Divisão de Orientação técnica, escreve que

Hoje, o ensino Municipal de São Paulo existe. Existe - não como um arremedo do Ensino estadual, existe como um ser individual, com personalidade definida, com características próprias, a serviço de uma Capital com quase oito milhões de habitantes, população essa a mais diversificada e por isso mesmo com exigências variadas. [...] De início, o Ensino Municipal prendeu-se ao modelo do Estado em estrutura administrativa e funcionamento. Tão logo tomou consciência de seu papel, talvez pela dinâmica própria de um grupo novo, com gente nova, com idéias, ele se viu impelido para uma atitude de renovação. E esse espírito de vanguarda vem norteando todo o seu desenvolvimento e dirigindo toda sua ação. (Escola Municipal, n. 6, dez., 1976, p. 4)

É preciso deixar claro que ao perceber a construção desse lugar de memória do ensino municipal, não se pretende reforçar um mito de origem, mas mostrar que a autonomia do município frente ao Estado foi construída nos edifícios e na linguagem. É um lugar imaginário, porque produto da relação entre o real e o simbólico. Real porque vinha sendo gestada por ações concretas antes mesmo de 1956. Simbólica porque ganhou um aparato discursivo que significou a realidade a partir de 1968 por meio de sua revista, deu-lhe um nome, quase como um ser individual, com personalidade definida no dizer da articulista, assegurou-lhe definitivamente seu lugar.

Os indícios sugerem que o modelo de gestão para o ensinar não possuía características pedagógicas definidas para seus professores, tal como no modelo escolar paulista ou na Pedagogia da Escola Nova, aliás, baseava-se neles, mas acentuava sua peculiaridade administrativa e burocrática que atestavam o crescimento da rede, do número de escolas e de um impresso que fizesse circular que este novo lugar estava construído. Era uma identidade sem sujeitos ou espaços específicos, ou melhor, um lugar vazio preenchido com a escrita, com as cifras, com a construção de novas escolas e de um currículo que deveria seguir as orientações gerais do governo federal.

Não havia a tentativa de construir uma identidade baseada em fatos históricos marcantes da região ou na criação de um novo modelo pedagógico. O modelo escolar paulistano era também o do lugar imaginário da nação moderna e pujante, baseado na gestão administrativa desconcentrada. É Marlene de Paulo Lattouff que chama atenção para esta diferença:

Os processos de descentralização e de desconcentração, segundo a ênfase na eficácia recaia, respectivamente, sobre o poder local ou o poder central. Assim, na desconcentração, há delegação de determinadas funções para entidades locais que dependem do outorgante, ligada portanto, à estrutura de decisão de poder. Já na descentralização, ocorre que as entidades locais imbuídas de graus de autonomia podem definir a sua organização e a administração do sistema de educação pública dentro da área que lhes compete, referindo-se à configuração espacial de uso e controle do poder. [...] Portanto, nem conceitual, nem temporalmente 
aplica-se, à ação do poder municipal no âmbito da educação e do ensino antes de 1988 a perspectiva da 'municipalização', que supõe a descentralização. A eficácia do poder local. As práticas municipais do passado foram, sobretudo, desconcentradoras, visando a assegurar a eficácia do poder central. (Lattouf, 2001, p. 14-17)

A revista Escola Municipal elegeu como símbolo a suposta neutralidade administrativa e burocrática de caráter nacional. Era um controle ainda desconcentrado, isto é, entre a disciplinarização e o controle, mas que procurava ao mesmo tempo se autonomizar do Estado de São Paulo e vincular-se às políticas nacionais de educação. Portanto, foi na escrita institucional que se arquitetou a dissensão entre Prefeitura e o Estado de São Paulo.

Figura 1

Capa da Revista Escola Municipal, número 10, 1981.

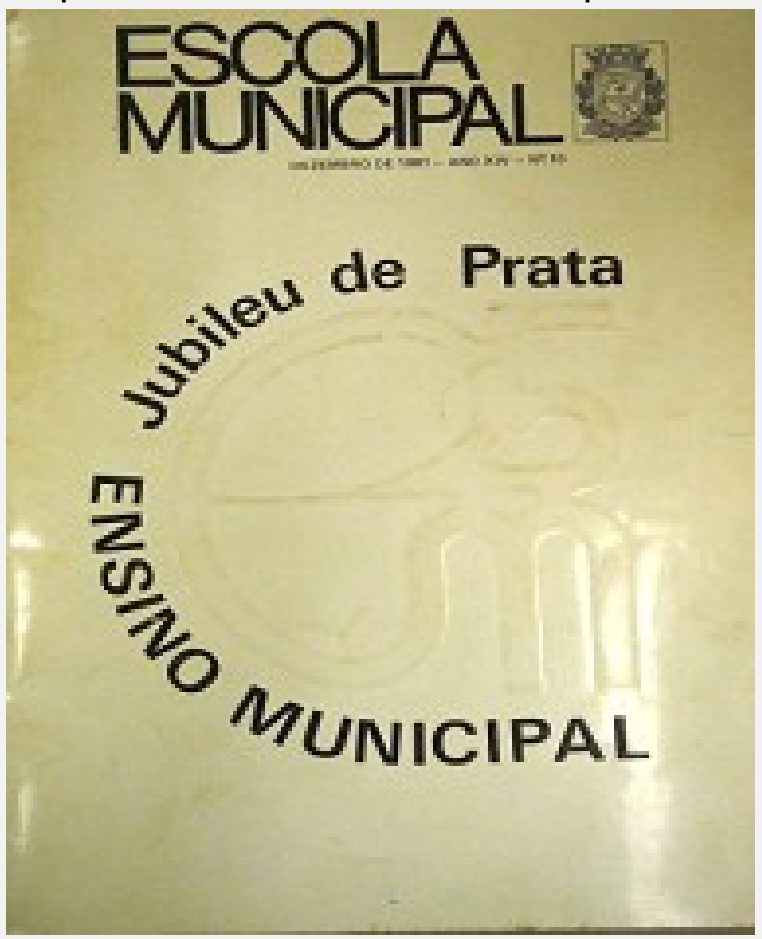

A capa de número 10 da revista Escola Municipal, de 1981, foi elegantemente produzida em alto relevo sobre um fundo branco. As letras "E" e "M" formavam a sigla "Ensino Municipal” e o número "25", atribuída à

profa. Damaris Lopes, da E.M de $1^{\circ}$ Grau Major Silvio Fleming, AR/MO, DREM 4, este símbolo foi escolhido através de concurso realizado pela Secretaria Municipal da Educação, sob coordenação da Divisão de Programas Especiais - Supeme - do qual participam professores, especialistas de Educação e funcionários ligados ao ensino municipal. $O$ concurso teve, entre outras, a finalidade de incentivar a pesquisa do histórico do ensino municipal e ressalta o valor dos trabalhos realizados nesses 25 anos de existência. (Escola Municipal, n. 10, dez., 1981, p. 3) 
Era a primeira capa da revista que não recorria ao uso da fotografia de crianças, jovens, de prédios escolares ou de comemorações cívicas e esportivas, pois o símbolo escolhido para representar o jubileu de prata era autorreferente, fechado, devidamente materializado em suas iniciais e que, por sua vez, desmaterializava seus sujeitos e espaços. Nesta capa, a burocracia como a escrita da instituição dominava o lugar, ganhava relevo na página, era ela que deveria representar a história do ensino municipal.

\section{As fases da revista: produção e circulação}

A revista Escola Municipal, dentre as publicações do período na cidade e do acervo pesquisado na biblioteca da Memória Técnica Documental da Secretaria da Educação Municipal de São Paulo, foi a de vida mais longa ${ }^{4}$ e, por isso, a que apresenta maiores variações em seu projeto editorial. Seus treze números foram publicados anualmente em um período de dezoito anos, com interrupções em 1970, 1972, 1973, 1979 e 1983. Podemos caracterizá-la em três fases distintas, no entanto, unidas em torno do modelo escolar paulistano.

As explicações para as interrupções na publicação são relativamente simples, pois a cada mudança de gestão havia uma reorganização das orientações administrativas do ensino municipal. Portanto, as variações em sua fórmula editorial dependiam mais das vicissitudes da gestão administrativa do que uma preocupação com a materialidade e o conteúdo do impresso. Por isso, não foi uma revista preocupada em inovar sua materialidade ou a forma de apresentar artigos, seções ou colunas, mas de apresentar as inovações administrativas da rede a cada mudança de gestão.

Aliás, sua fórmula editorial repetia os modelos das revistas pedagógicas dos anos 1960, diferente do que se verificava em publicações dos anos 1970, tal com a revista Escola, produzida pela Editora Abril entre 1971 a $1974^{5}$. Nesta revista havia preocupação de incorporar elementos do jornalismo editorial mais contemporâneo, como o fotojornalismo, de modo a torná-la mais atrativa para a venda e a circulação dos saberes escolares ligados aos da reforma da escola de oito anos oriundos da lei n. 5.692/71. Os autores também tiveram a preocupação de investigar os vínculos entre a Editora Abril e o regime militar que foram apagados na atualidade, o que contribuiu para instaurar uma desmemória do regime.

Não foi esse o caso da revista Escola Municipal, que além de possuir menos recursos financeiros do que sua congênere e mais entraves institucionais, não fazia questão de esconder sua vinculação com a oficialidade, visto que produzida por um órgão de governo ligado às diretrizes educacionais federais, ainda que não fizesse apologia da

\footnotetext{
${ }^{4}$ Há outras duas publicações importantes que não serão abordadas neste artigo, mas que se relacionam com a revista "Escola Municipal": a "Revista do Ensino Municipal" publicada uma única vez no mês de março de 1970, basicamente editada para fazer circular e explicar a implantação do currículo da escola integrada de oito anos no Município de São Paulo durante a gestão do prefeito Paulo Salim Maluf; e o jornal "Paulicéia Educação", publicação trimestral em formato tabloide que circulou entre 1983 a 1985 , durante a gestão do prefeito Mário Covas. A primeira foi publicada no ano em que sua congênere deixou de circular, embora não possa ser vista como uma continuidade da revista "Escola Municipal" possui semelhanças em seu formato editorial. A segunda foi o laboratório para a construção da última fase da revista "Escola Municipal", embora tenha sido editada concomitantemente. Outras publicações do município encontradas no arquivo da Memória Técnica do Ensino Municipal não tratam especificamente do ensino, mas de aspectos da administração pública da cidade.

${ }^{5}$ Ver Maria Rita de Almeida Toledo e Daniel Revah (2011).
} 
ditadura militar. Tal vinculação marca o modelo escolar paulistano de caráter nacionalista, burocrático e administrativo. É somente na última fase da revista que se nota uma mudança na materialidade do impresso e do conteúdo.

A primeira fase de 1968-1969 (n. 1 e 2, respectivamente em 1968 e 1969) pode ser considerada a de experimentação da revista, período durante o qual documentou e reforçou a tentativa de construir uma rede de ensino primário mais coesa e uniforme. Prevaleciam as características pedagógicas da publicação em sala de aula, mais do que questões administrativas e políticas. As revistas de número 1 e 2 foram publicadas durante a gestão do prefeito José Vicente de Faria Lima.

A segunda fase, de 1971-1982, (n. 3, 4, 5, 6, 7, 8, 9, 10 e 11, respectivamente em 1971, 1974, 1975, 1976, 1977, 1978, 1980, 1981 e 1982), foi marcada pela estabilização da revista e pelo forte crescimento do ensino municipal, principalmente com a implantação da escola de oito anos (1971), que abolia a divisão entre o ensino primário e secundário e os exames de admissão para o ginásio, formando um único ciclo formativo, com o ensino de primeiro grau.

No entanto, as questões pedagógicas cederam lugar às questões administrativas e aos problemas inerentes à criação de um sistema que atendia a um diversificado público escolar. A revista de número 3 foi publicada durante a gestão do prefeito José Carlos de Figueiredo Ferraz, as revistas de número 4 e 5 na gestão de Miguel Colasuono, as de número 6, 7 e 8 na gestão de Olavo Egídio Setubal, as de número 9 e 10 na gestão de Reynaldo Emygdio de Barros e a de número 11 na gestão de Antonio Salim Curiati.

A terceira fase de 1984-1985 (n. 12 e 13, respectivamente em 1984 e 1985), foi a que apresentou maiores rupturas e pode ser considerada a de crítica aos projetos editoriais anteriores da revista. Concomitantemente, verificava-se a consolidação do sistema municipal de ensino de primeiro grau na cidade e das contradições entre qualidade de ensino e quantidade de alunos na rede. As questões técnico-administrativas deixavam de ser o foco principal e passaram a ser vistas de forma atrelada às questões políticas e pedagógicas. O enfraquecimento da ditadura militar e a redemocratização favoreceram uma postura de crítica ao regime, ao próprio sistema e as desigualdades sociais dentro e fora das escolas. As revistas de número 12 e 13 foram publicadas durante a gestão do prefeito Mário Covas.

A revista Escola Municipal tinha periodicidade anual e foi publicada nos meses de fevereiro (n. 2), setembro (n. 1 e 3), dezembro (n. 4, 5, 6, 7, 8, 9, 10 e 11), e as duas últimas (n. 12 e 13) não indicaram o mês. O formato médio da revista era de $20 \mathrm{~cm} x$ $26,5 \mathrm{~cm}$. A revista apresentava capa colorida em todas as suas publicações e o conteúdo em preto e branco, inclusive o das imagens, com exceção de algumas poucas propagandas na contracapa e na última ou penúltima capa. A preferência foi a de publicála no final do ano para o melhor planejamento da produção editorial da revista. Além disso, para que as ações da prefeitura pudessem ser divulgadas, bem como estudos, diagnósticos e notícias sobre a situação do ensino fossem avaliados pela própria administração pública. Tal periodicidade favorecia também a pesquisa e publicação de 
estudos estatísticos de longa duração presentes em diversos números, sobretudo, a partir da segunda fase da revista ${ }^{6}$.

A revista demorava, em média, um ano para ser produzida, mas é interessante observar no material coletado na Memória Técnica do Ensino Municipal os detalhes de sua produção. Na pasta de número DO. 2/Pj. 003/83 é possível ler a seguinte justificativa para o projeto de mais um número da revista Escola Municipal de número 12, planejada em 1983, ano em que a revista não circulou, para o ano de 1984:

Necessidade do Departamento de Planejamento e Orientação ter um instrumento de ampla divulgação das realizações do Ensino Municipal, e também permanente comunicação entre os órgãos da própria Secretaria Municipal de Educação e outros. (DO. 2/Pj. 003/83, p. 2)

Tal necessidade não era nova, mas estava presente desde os primeiros números da revista, embora enfatizasse mais seu caráter de revista pedagógica na primeira fase e ganhasse contorno mais administrativo a partir da segunda fase. Nesta terceira fase, a revista tinha características políticas e pedagógicas, no entanto, as questões administrativas não foram abandonadas, mas atreladas às discussões de democratização da escola e da sociedade próprio daquele período. Observava-se, porém, a continuidade de uma visão administrativa nos objetivos pretendidos:

Promover junto à Rede Escolar a divulgação de informações de interesse do Ensino. - Facilitar ao pessoal envolvido no processo educacional o acesso aos resultados dos trabalhos realizados pelos diversos órgãos da Secretaria Municipal de Educação. - Documentar a vida do Ensino Municipal, constituindo-se em permanente fonte de consulta. - Realizar um trabalho informativo, de âmbito nacional, sobre o Ensino Municipal de São Paulo. - Incentivar as Escolas Municipais a divulgarem suas realizações. (DO. 2/Pj. 003/83, p. 3)

As justificativas e objetivos da produção da revista como instrumento de divulgação e comunicação entre os órgãos do ensino municipal, de documentação da vida do ensino municipal e sua preocupação de nacionalizar tais informações, confirmam a hipótese de que o periódico, embora tenha passado por diferentes fases, mantinha a caraterística do modelo escolar paulistano: o controle da rede por meio da comunicação permanente para reforçar a unidade entre os diferentes órgãos que a compunham e sua coesão administrativa divulgada em âmbito nacional.

O único objetivo não realizado em todos os números foi a divulgação das realizações das escolas municipais. Embora a revista contasse com a participação de professores da rede, tais colaborações eram de professores alocados nos órgãos do ensino municipal ou em cargos de direção. Além disso, as informações sobre as escolas eram fornecidas por agentes externos e não por iniciativa da comunidade escolar. Ademais, os atrasos eram constantes e a falta de colaboradores internos das escolas deveria dificultar o trabalho de

6 Essas informações foram coligidas em entrevista realizada em 6/2/2012 com a revisora do periódico, Sidoni Chamoun, durante quatro números da revista Escola Municipal (1975-1978). Sidoni Chamoun é hoje responsável pelo arquivo da Memória Técnica do Ensino Municipal e principal organizadora do seu acervo, que passa por um processo ostensivo de digitalização. 
edição e publicação da revista, conforme podemos notar numa comunicação feita no Diário Oficial do Município de 18 de março de 1980:

A Diretora do Departamento de Planejamento, Orientação e Controle, tendo em vista a necessidade de retificar a publicação, de 31.01.1980, referente a [sic] Revista "Escola Municipal", comunica-se que o número 9 (nove) do referido periódico, que teria circulação prevista para junho de 1980, deverá circular somente no final de 1980, encontrando-se em fase de preparação na Seção de Documentação e Divulgação - DEPLAN 22 da Divisão de Planejamento. [...] Fica, portanto, prorrogado até 30.06.1980, o prazo para recebimento das colaborações dos órgãos Técnicos e Administrativos de [sic] S.M.E., bem como das Escolas da Rede Municipal de Ensino para a publicação da referida revista. [...] As notícias e matérias técnicas deverão ser datilografadas em espaço duplo contendo nome completo, do (s) autor (s), local de exercício, cargo ou função desempenhada e encaminhadas ao DEPLAN 22 - sala 19. [...] São de maior interesse essas colaborações, pois a revista "Escola Municipal" deve ser porta-voz das experiências e atividades que são desenvolvidas pela Secretaria Municipal de Educação (Diário Oficial do Município de São Paulo, 18/03/1980: 31)

A lentidão na produção da revista era um retrato da extrema burocratização da rede e do controle administrativo que contava com inúmeros órgãos, departamentos, seções e de colaboradores externos e internos. É importante destacar que o comunicado no Diário Oficial era voltado aos órgãos técnicos e administrativos e escolas municipais, enquanto que a finalidade da revista era a de ser porta-voz da Secretaria Municipal da Educação. Os setores administrativos ficavam em primeiro plano no planejamento da revista em detrimento das escolas municipais.

Embora o modelo escolar paulistano prescrevesse maior rapidez e circulação de informações da rede para uma gestão administrativa racional, na prática verificava-se que a produção de tal velocidade era acompanhada justamente pela burocratização e morosidade das ações. Bom exemplo disso eram as inúmeras etapas de produção da revista de n. 12, para o ano de 1984, que começaram no final de 1982 e compreendia muitas fases de execução.

A primeira etapa, em setembro de 1982, de "providências preliminares", começou com a primeira fase de "reserva de verbas" pela secção de "Obras e Programas" sob a responsabilidade da chefia do Deplan 2. Em dezembro de 1982, a segunda fase de "providências dos recursos humanos" de "solicitação à chefia do Deplan pelo Deplan 2". Em abril de 1983, a terceira fase de "definição da estrutura da revista com a reunião com os elementos do Conselho Editorial", além da "designação de um responsável de cada órgão para garantir a entrega de matéria dentro dos prazos solicitados". Ainda em abril do mesmo ano, a quarta fase de "preparação do material de apoio" com a "elaboração do cronograma de atividades, comunicado a ser publicado no DOM e confecção de circulares de instruções, orientações e convites". Ainda no mesmo mês, a quinta e última fase da primeira etapa de "solicitação de colaborações" a ser distribuída por meio de "circulares e convites" a "assessoria técnica de SME, DSE, Supeme e Deplan" (DO. 2/Pj. 003/83, p. 5).

A segunda etapa de "recebimento de toda matéria a ser publicada" se iniciou entre maio e junho de 1983, com a sexta fase de "contatos com todos os órgãos da SME" com 
a observância da "atuação de cada elemento (previamente designado) junto ao órgão de sua responsabilidade". Ainda nestes meses, a sétima fase e última da segunda etapa de "contatos com os colaboradores" de "informações e esclarecimentos, pessoalmente ou por telefone" (DO. 2/Pj. 003/83, p. 5).

Na terceira etapa de "tratamento do material recebido" começou a oitava fase, entre julho e agosto de 1983, de "seleção dos artigos" com a "leitura e análise por equipe especializada". Nos mesmos meses, a nona fase de "tratamento do material selecionado" de "reformulações de artigos (nova redação) pela própria equipe ou com o autor, revisão, nova datilografia, revisão de todos os originais aproveitados, redação das notícias, legendas, textos de capa, seleção das fotos, organização dos gráficos, tabelas e ilustrações" (DO. 2/Pj. 003/83, p. 5).

A quarta etapa de "preparação final de matéria a ser impressa" começou no mês de setembro de 1983 (um ano, portanto, após a "reserva de verbas" da primeira etapa), com a décima fase de "montagem das capas" na "seleção de matéria" e sua "escolha pelo secretário" [provavelmente da Educação do Município]; com a décima primeira fase de "datilografia de toda matéria"; a décima segunda de "revisão", isto é, de "leitura, correções, etc."; e, finalmente, a décima terceira fase de "organização final do conteúdo", ou seja, "distribuição da matéria em função de sua estrutura (previamente definida): sequência de artigos, colocação das fotos e ilustrações, páginas centrais, etc." (DO. 2/Pj. 003/83, p. 5).

A quinta etapa era a de "contatos com a Gráfica Municipal de S. Paulo" que deveria começar com a décima quarta fase de "orçamento, pela gráfica municipal" necessitando do "contato da Chefia de Deplan 2 com o gerente geral da gráfica" em setembro de 1983. Em outubro e novembro de 1983, a décima quinta fase de "composição e impressão" com "contatos contínuos com a Seção de Fotocomposição da Gráfica Municipal". Ainda nos mesmos meses, se iniciaria a décima sexta fase de "acompanhamento do serviço" de "revisão dos textos compostos". No mês de novembro de 1983, a décima sétima fase de "impressão gráfica" (DO. 2/Pj. 003/83, p. 5).

A sexta e última etapa era a de distribuição. Ainda em novembro de 1983 começou a décima oitava fase de listagem com a seleção dos contemplados, isto é, dos órgãos e das escolas que receberiam as revistas. E, finalmente, a última fase de expedição, com o despacho: via Diretoria Regional de Ensino Municipal, por correio ou pessoalmente das revistas em dezembro de 1983.

Em função dessa morosidade na produção, não poderia concorrer com as revistas pedagógicas comerciais do período, tal com a revista Escola citada anteriormente. Além disso, sua forma de produção quase artesanal contrastava com o discurso da revista sobre a racionalidade administrativa da rede municipal. Porém, o modelo escolar paulistano, assim como todo modelo escolar, tornava-se uma diretriz de ação que era apropriada pelas práticas dos sujeitos em seus espaços escolares e institucionais dos quais emergiam os conflitos e as tensões.

Supondo que o planejamento acima fosse executado à risca, o que é bastante duvidoso pela sobreposição de datas das etapas e fases, além dos inúmeros agentes envolvidos em sua produção, os órgãos e escolas municipais receberiam as revistas durante todo o ano de 1984. Ou seja, a anuidade da revista correspondia sempre ao ano anterior de sua produção, ainda que os textos e as anuidades fossem corrigidos para 
corresponder ao ano de circulação. Tais dispositivos editoriais visavam criar uma imagem de celeridade, acompanhamento, continuidade, dinamismo, racionalidade e produtividade administrativa que só pode ser questionada a partir da análise da produção material da revista.

As revistas de número $1,2,3$ e 4 circularam em âmbito municipal e sem a informação sobre as tiragens. A partir do número 5 foram informadas as seguintes tiragens: 10.000 exemplares (n. 5), 15.000 exemplares (n. 9), 20.000 exemplares (n. 6, 7, 8 e 10), 25.000 exemplares (n. 11 e $12^{7}$ ). A revista de número 13 não apresentou a tiragem. Na revista de n. 5 informava-se, ainda, que

a revista 'ESCOLA MUNICIPAL' circulou pela primeira vez em setembro de 1968, para a divulgação de trabalhos pedagógicos, com a colaboração de professores, como Órgão do Departamento Municipal de Ensino, da Secretaria Municipal de Educação, da Prefeitura do Município de São Paulo. O n. 1 - Ano I, teve sua distribuição restrita ao âmbito do Ensino Municipal. Seguiram-se o n. 2, em fevereiro de 69, também registrado no Ano I, e o n. 3 - Ano III, setembro de 71, em edição comemorativa aos 15 anos de atuação do Ensino Municipal. Nos anos 70, 72 e 73, a 'ESCOLA MUNICIPAL' deixou de ser publicada, voltando a circular o n. 4 - Ano IV, em dezembro de 1974. A presente publicação, editada em dezembro de 75, circula sob o n. 5 - Ano VIII, para obedecer à numeração correta, a partir de sua fundação, em 1968. Com 52 páginas, a Revista terá seus 10.000 exemplares distribuídos a órgãos e pessoas ligadas ao Ensino no âmbito municipal, estadual e federal. (Revista Escola Municipal, n. 5, ano 8, dez., 1975, p. 42.)

A informação era da própria revista, entretanto, podemos constatar que a partir do número 5 (1975) mais detalhes sobre a editoria foram fornecidas no expediente do que nas edições anteriores, o que podia indicar a preocupação de identificar os vários agentes envolvidos na sua elaboração para um público mais amplo do que aquele destinado à cidade de São Paulo.

Havia, explicitamente, uma tentativa de aproximar os propósitos nacionalistas desse modelo escolar com a maior circulação da revista para outras cidades e regiões do Estado e do país, principalmente a partir do número 6 de 1976 quando, pela primeira vez, aparece uma coluna de agradecimentos recebidos, que só retornaria na revista de número 11 de 1982, sempre na última página da revista, ou nos números 7 e 8 ,

\footnotetext{
${ }^{7}$ A tiragem desta edição pode ser coletada no material de preparo do Departamento de Planejamento e Orientação do projeto da revista Escola Municipal no ano de 1983 para o ano de 1984 na pasta de número DO. $2 / \mathrm{Pj}$. 003/83, documento comentado longamente nas páginas acima. Tal dado não aparece no expediente da revista.
} 
respectivamente de 1977 e de 1978, quando surge uma seção denominada de cartas no expediente da revista. ${ }^{8}$

A correção da anuidade da revista a partir do número 5 visava a elidir as interrupções da publicação e demonstrar uma idéia de continuidade que nem sempre pareceu certa, mas que foi devidamente aproveitada em todas as suas fases. Exemplo disso era que o último número da revista (n. 13) indicava ano 18 , desconsiderando as interrupções de anos anteriores. A própria revista fundava a sua memória histórica, isto é, construindo uma idéia de perenidade que não estava colocada para seus agentes nos vários momentos de produção e circulação, mas que serviriam de modelo de gestão administrativa.

Por não ser uma revista comercial e de distribuição gratuita para as escolas municipais e diversos órgãos governamentais, as tiragens das revistas aumentaram consideravelmente ano a ano, duplicando nos números subsequentes ( $\mathrm{n} .6,7$ e 8 ) com 20.000 exemplares, decrescendo para 5.000 exemplares no número 9 , mas retomando o crescimento para 20 a 25.000 exemplares na fase final da revista (n. 10, 11 e 12).

O número de páginas é bastante heterogêneo, com aumento na edição comemorativa do jubileu de prata do ensino municipal em 1981 (n. 10) com 84 páginas. Nas demais temos: 32 páginas (n. 4), 48 (n. 1 e 2), 52 (n. 5), 56 (n. 06), 60 (n. 11 e 12), 64 (n. 7, 8 e 13), 68 (n. 3 e 9). As maiores edições foram aquelas que, além da publicação de artigos, seções, colunas fixas e imagens, apresentavam abundância de material legislativo sobre a educação e o magistério municipal, característica da segunda fase da revista de cunho mais administrativo.

Resta ainda discutir a partir da relação entre forma e conteúdo da publicação o tipo de leitor a ser atingido dentro desse modelo escolar.

\section{Apropriação como reformismo: o leitor professor-administrador}

Os dados sobre a produção e a circulação da revista atestam que sua fórmula editorial estava intimamente ligada a esse modelo escolar de gestão para o ensinar, isto é, dava-se mais atenção à organização burocrática e administrativa da rede, a qual prescrevia o controle do lugar de ensino e autopromoção de seus feitos em âmbito nacional do que aos saberes pedagógicos. Obviamente, tal modelo criava um tipo de leitor ideal, mas sem deixar de lado as múltiplas formas de apropriação que apareciam no

\footnotetext{
${ }^{8}$ Cabe informar que em nenhuma destas seções ou colunas aparecem críticas negativas dos leitores sobre a revista, apenas acuso de recebimentos, agradecimentos e/ou elogios. Os locais de recebimentos são da cidade, do interior e de diversas regiões ou cidades do país tais como, por exemplo, na revista de número 6 de 1976: "Escola de Serviço Social (Biblioteca) Araraquara; Divisão de Documentação do Departamento de Administração do Munícipio de São Paulo; Secretaria de Educação e Cultura do Estado da Paraíba; Biblioteca da Associação São Bento de Ensino-Araraquara; Centro de Documentação da Secretaria da Educação e Cultura do Rio Grande do Sul; Instituto de Educação Estadual 'Dr. Cesario Coimbra' - Araras; Instituto Santa Teresa - Lorena; Departamento de Educação e Cultura da Prefeitura de Araçatuba; Escola Municipal de $1^{\circ} \mathrm{Grau}$ 'João Carlos da Silva Borges'; Conselho Estadual de Educação - Secretaria de Educação e Cultura da Prefeitura de Sergipe; Conselho Estadual de Educação - Pernambuco; Prefeitura Municipal de Restinga - SP; Secretaria de Educação e Cultura do Mato Grosso; Prefeitura Municipal de Campo Grande (MT); Secretaria de Educação e Cultura do Rio Grande do Sul; Biblioteca Municipal Mario de Andrade - São Paulo; Osiro Silveira - deputado estadual; Maria Terezinha Tourinho Saraiva - secretária de Educação e Cultura do Estado do Rio de Janeiro; Raymundo de Mattos Serrão - presidente do Conselho Estadual de Educação do Estado do Maranhão; Caio Pompeu de Toledo - secretário municipal de Esportes - São Paulo."
} 
conteúdo da revista, neste caso, no reformismo que marcou a atuação do governo municipal em matéria educativa na época da ditadura militar. Trata-se de um leitor de tipo híbrido entre o professor e o administrador.

Cabe comentar três exemplos de apropriação reformista que configura esse modelo escolar e o tipo de leitor desejado pelo periódico em suas diferentes fases. A primeira fase, mais pedagógica, é sobre a questão do currículo do ensino primário e as práticas pedagógicas em sala de aula. A segunda fase, mais administrativa, sobre os tipos de materiais nos quais a revista se baseava para divulgar os dados estatísticos sobre o ensino municipal. E a terceira fase, mais política, a dificuldade em romper com a gestão administrativa do período anterior, mesmo em sua fase democrática e de crítica aos projetos editoriais anteriores da revista e da escola municipal.

$\mathrm{Na}$ sua primeira fase, a revista informava que o currículo para o ensino primário permanecia inalterado desde 1949 e um novo programa foi implantado no ano de 1968, data simbólica para a autonomia da rede, embora seguisse o currículo e programas do curso primário do Estado. Foi inspirado nos métodos ativos da Escola Nova para "o desenvolvimento do raciocínio; o desenvolvimento das atividades de expressão da criança; a integração desta mesma criança no meio físico e social", dizia o artigo da professora Margarida Maria de Souza Campos Rios na revista Escola Municipal de 1969:

Para que tais finalidades? Para buscar os "ideais de liberdade", do "desenvolvimento da personalidade humana" e da "sua participação na obra do bem comum" [...] Objetivos da escola primária [...] - Os que abrangem "comportamentos inteligentes": aquisição de conhecimentos, de informações, formação de conceitos e generalizações. [...] Os que abrangem "comportamentos afetivos": - desenvolvimento de atitudes, de julgamentos e de apreciação. [...] - Os que abrangem "comportamentos automatizantes": - formação de hábitos, desenvolvimentos de habilidades. [...] Daí os objetivos do Ensino Primário, tais como eles se apresentam no novo programa de ensino: $O$ ensino primário deve propiciar condições para que a criança: 1 - Desenvolva hábitos e atitudes adequadas em relação à saúde e ao desenvolvimento físico. 2 - Raciocine com lógica. 3 - Aprenda a ler, escrever e calcular com precisão e desembaraço. 4 - Adquira conhecimentos adequados ao seu nível de desenvolvimento. 5 desenvolva a criatividade. 6 - Tenha responsabilidade. 7 - Desenvolva a sociabilidade. [...] III - Análise do programa [...] 1- O programa para o ensino primário na Escola Primária procura ser intencionalmente "singelo". [...] 2 - O programa para o ensino na Escola Primária é "experimental". [...] 3 - O Programa para o ensino na Escola Primária caracteriza-se pela ausência de "indicações metodológicas". (Escola Municipal, n. 2, 1969, p. 9-10)

Do ponto de vista do currículo pré-ativo (Goodson, 1995), não havia nenhuma novidade pedagógica. O modelo seguido era o das ciências da educação em voga desde os anos 1920 com a Pedagogia da Escola Nova, embora o artigo não apresente 
indicações bibliográficas ${ }^{9}$. O que parecia ser novo era justamente a falta de clareza: singeleza, experimentalismo e ausência de indicações metodológicas. O modelo escolar paulistano se apropriava de modelos pedagógicos pré-existentes não para segui-los com o posicionamento político-pedagógico que originaram sua elaboração, mas para justificar a existência da sua rede. Logo, a simplicidade, a experimentação e a ausência de metodologia eram indícios de que importava menos a orientação pedagógica na sala de aula e mais o de reproduzir princípios gerais de modelos pedagógicos que não impedissem o funcionamento escolar.

Tratava-se de usar um modelo pedagógico não na perspectiva de disciplinar a metodologia em sala de aula, mas para garantir que professores e alunos cumprissem o currículo de maneira mais simples e aberta possível. Ou seja, controlava-se não por meio da teoria, mas de uma prática que habituasse discentes e docentes para sua constante reformulação, principalmente em caso de malogro. O professor-leitor deveria ser um administrador em sala de aula para lidar constantemente com a reformulação de conteúdos e modos de ensinar. É preciso lembrar novamente com Gilles Deleuze de que "num regime de controle nunca se termina nada" (Deleuze, 1990, p. 215-216).

Desta forma, a articulista insiste que "há necessidades de uma reformulação de todas as atividades para que se adaptem à estrutura social na qual a escola acha-se inserida" (Escola Municipal, n. 2, 1969, p. 9). Para o nível 1, primeira e segunda séries, o enfoque era para o ensino da Língua Pátria, e para o nível 2, segunda e terceira séries, nas áreas de estudo de Língua Pátria, Matemática, Estudos Sociais, Ciências, Saúde, Educação Física e Iniciação Artística. Ainda: "quanto à Educação Cívica, não há programação isolada. Pela sua natureza e finalidade ela precisa estar presente em todos os momentos de trabalho do professor e, também, será desenvolvida em festas e comemorações escolares" (Escola Municipal, n. 2, 1969, p. 11).

O artigo termina com um último e relevante assunto sobre o período preparatório para executar o programa, mas tal período não era apenas para o aluno:

E nisto reflita o professor que, qualquer deficiência na aquisição de alguns dos aspectos citados, torna o ensino mais difícil ou mesmo improfícuo. Nesse caso a tentativa de ensinar resulta quase sempre em fracasso e frustração que podem condicionar no indivíduo a formação de uma atitude de permanente desinteresse pelo estudo, o que será, verdadeiramente, lastimável. (Escola Municipal, n. 2, 1969, p. 11)

As profecias curriculares da articulista se concretizaram, pois a implantação do Plano de Educação Infantil - Planedi, em caráter experimental na rede desde 1973 e institucionalizado em 13 de fevereiro de 1976, pelo decreto n. 12.637, visava a preparar os alunos da educação infantil para melhor se integrarem ao currículo da escola de oito anos, tendo vista os altos índices de evasão e repetência observados na primeira série do

\footnotetext{
${ }^{9}$ Em artigo já citado nas páginas acima, Marta Maria Chagas de Carvalho (2011, p. 202), afirma que "com objetivos de sistematização e síntese, Introdução ao estudo da escola nova, livro-manual de Lourenço Filho publicado, originalmente, em 1930, foi um livro muito bem-sucedido. Estruturado em cinco lições didaticamente expostas e com um pouco mais de duzentas páginas, foi um sucesso editorial. Nesse formato e com essa estrutura simples, alcançou três edições com tiragens significativas no espaço de três anos. Revisto, aumentado e depois refundido, foi reeditado até 1979, alcançando treze edições", o que demonstra a força da pedagogia da Escola Nova ainda nos anos 1960 como modelo pedagógico, inclusive para a recente rede de ensino municipal primário.
} 
primário $^{10}$. O Planedi de 1976 atestava que o currículo prescrito para as escolas, em 1968, se constituiu em verdadeiro fracasso não por falta de aplicação, mas pelo reformismo controlador que se apropriava dos saberes pedagógicos mais para justificar suas práticas de gestão administrativa do que solucionar problemas educativos em sala de aula. O que importava era manter as cifras, o número progressivo de crianças na rede escolar e o aumento das construções escolares ${ }^{11}$. Desta forma, o professor se tornava um administrador das dificuldades que a própria rede impunha como solução para seus conflitos.

Outro exemplo de reformismo da rede, mas que se reflete na própria materialidade do impresso, era a seleção do conteúdo informativo, principalmente de pesquisas estatísticas que compunham a segunda fase da revista de caráter mais administrativo. Não eram materiais exclusivos da revista, mas produzidos em função da medição entre reformas curriculares pretendidas e as que foram alcançadas a cada mudança de gestão municipal, que depositavam nas estatísticas uma forma de comprovar a sua eficácia administrativa (figuras 2 e 3 ).

\footnotetext{
${ }^{10}$ No material legislativo publicado na revista Escola Municipal de 1976 havia constante preocupação em mostrar a consolidação da rede e a sua relação com o sistema de ensino de primeiro grau do município que procurava se firmar ano após ano, registrava-se que: "instituído oficialmente, o Planedi [...] consiste essencialmente, na inserção da pré-escola nas Escolas de $1^{\circ} \mathrm{Grau}$. Destina-se à preparação de crianças com faixa etária de 3 a 7 anos, para o ingresso adequado na $1^{a}$ série. Servindo-se de recursos físicos, aparelhamento e infraestrutura já existentes, permite atender à grande demanda, em curto prazo de tempo. Após os ótimos resultados alcançados de forma experimental em 1975, o Planedi, agora em termos definitivos, deverá ser estendido, até o final do ano, a 110 Unidades de $1^{\circ}$ Grau da Rede Municipal de Ensino" (Escola Municipal, n. 6, 1976, p. 35). Com isso, pretendo mostrar que muitas das "inovações curriculares" adotadas pela administração municipal nos anos 1970 foram frutos de uma gestão mais preocupada em corrigir e reformular seus problemas do que buscar soluções efetivas de ensino-aprendizado.

${ }^{11}$ Em entrevista realizada em 13 de fevereiro de 2012, com Ethel Cristina Fernandes de Souza Dias, que foi aluna do primário nos anos 1970 da Escola Municipal Comandante Gastão Moutinho, onde atualmente é assistente de direção, pode-se perceber as dificuldades também na implantação do Planedi: "Eu lembro que aqui nessa escola funcionava um Planedi, que devia ser uma coisa de maluco. Porque era uma professora para muita criança, muita. E eu lembro que mesmo eu sendo criança, eu me admirava com a quantidade de aluno que aquela professora cuidava. Porque a sala era muito grande. Não era uma sala de aula. Era um espaço muito grande. Porque eram muitas crianças juntas. E eu lembro que achava assim uma coisa [...], como aquela professora conseguia dar aula naquele espaço tão grande. Hoje em dia eu sei que era um projeto e que havia mães monitoras, mas naquela época eu não lembro de enxergar essas mães. Eu só lembro de enxergar a professora e um bando de criança numa sala de aula muito grande. E como eu sempre tive experiência de sala de aula por acompanhar minha mãe. Como falei onde minha mãe ia, eu ia junto, então eu entrei na escola muito nova e fui passando por todos [...] pré-escola, e sempre tinha essa vivência do que era pré-escola e de uma sala de aula com número de alunos. Então eu lembro que era uma coisa que me marcou. Esse Planedi, com uma professora e uma quantidade muito grande de alunos. E a sala ficava nesse prédio do lado, que era um prédio anexo, e normalmente a gente fazia o recreio atrás onde hoje em dia tem plantado umas árvores. A gente ia pra lá fazer o recreio sentada lá, e eu lembro que eu via então essa professora dando aula pra essa multidão de criancinhas de camiseta branca e shorts vermelho. Era o uniforme. Camiseta branca e shorts bufante vermelho, então eu me lembro que isso me chamou atenção".
} 
Figura 2

Trecho selecionado do Relatório de 1976, da Secretaria Municipal da Educação, gestão do prefeito Olavo Egydio Setúbal, p. 14.

A. 3 -Unidades Escolares - O Ensino Municipal conta atualmente com 273 Escolas Municipais de $1 .^{\circ} \mathrm{Grau}$, sendo que mais de setenta por cento estāo localizadas em bairros periféricos, cujas populaçōes, em geral, apresentam baixa renda familiar e nível-cultural equivalente.

As Escolas Municipais de $1^{\circ}$. Grau estão distribuidas pelas Administrações Regionais, da seguinte forma:

\begin{tabular}{|l|c|}
\hline \multicolumn{1}{|c|}{ AR } & No.de Escolas \\
\hline 1. Butantã & 16. \\
2. Campo Limpo & 20 \\
3. Freguesia do Ó & 21 \\
4. Ipiranga & 11 \\
5. Itaquera-Guaianazes & 27 \\
6. Lapa & 3 \\
7. Moóca & 13 \\
8. Penha & 22 \\
9. Pirituba-Perus & 21 \\
10. Pinheiros & 2 \\
11. Santana & 30 \\
12. Samaro & 31 \\
13. São Miguel - Ermelino Matarazzo & 19 \\
14. Sé & 4 \\
15. Vila Mariana & 10 \\
16. Vila Prudente & 23 \\
\hline TOT AL & 273 \\
\hline
\end{tabular}




\section{Figura 3}

Primeira página da matéria de abertura da revista Escola Municipal de 1977, n. 7, gestão do prefeito Olavo Egydio Setúbal, p. 4.

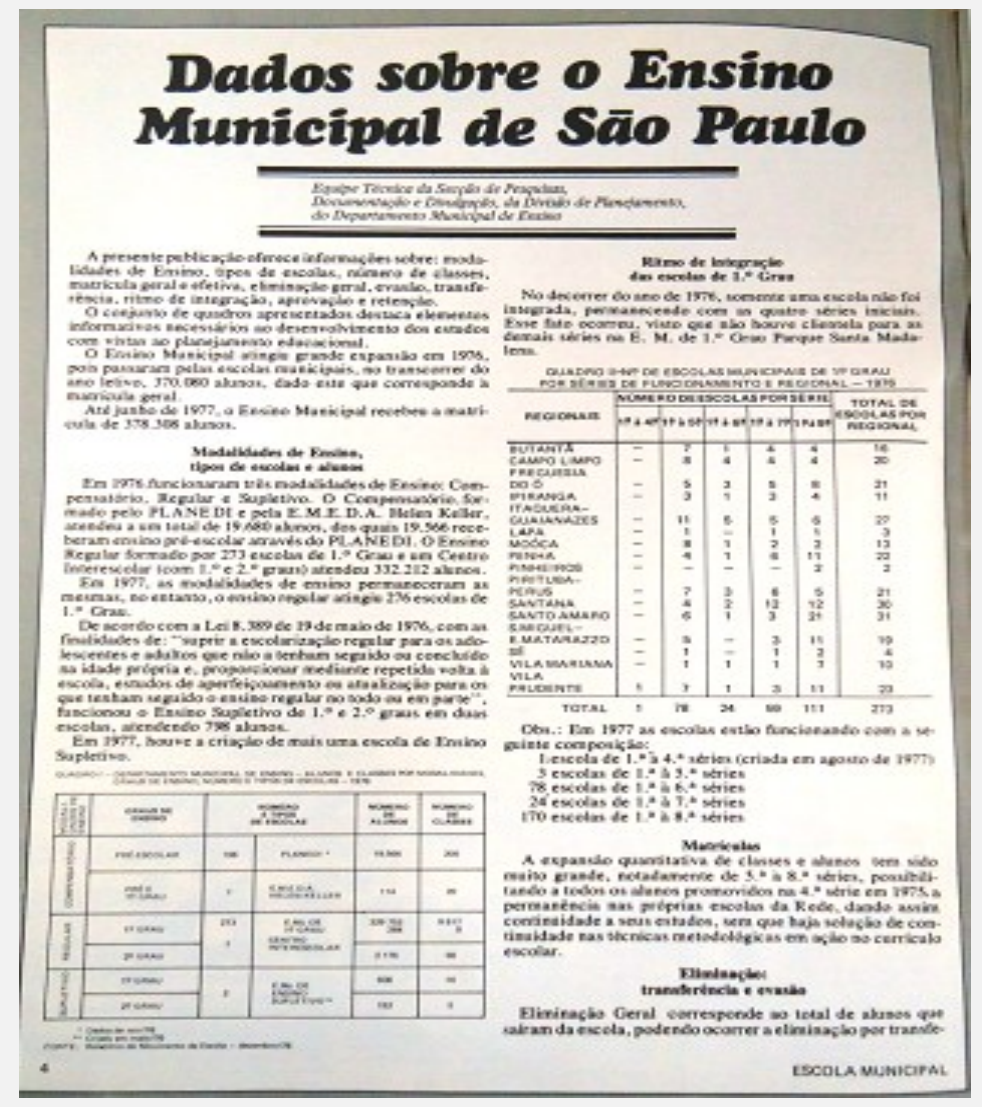

Os dados estatísticos da revista eram provenientes das inúmeras seções dos departamentos do ensino municipal responsáveis por elaborar estudos e pesquisas sobre a rede. A cada final de ano havia produção de relatórios quantitativos detalhados e que eram utilizados na revista Escola Municipal. O fragmento do relatório de 1976 acima é apenas um entre os vários encontrados no arquivo da Memória Técnica do Ensino Municipal. Tive acesso aos seguintes relatórios dos anos de 1971, 1976, 1977, 1978, 1979/82, 1981, 1983/85. Esse era o principal material estatístico de composição da revista Escola Municipal, não apenas em sua segunda fase mais administrativa como também em sua última fase mais política e democrática.

Os dados da tabela do relatório de 1976 (figura 2) foram utilizados na revista de número 7 , de 1977, (figura 3, segunda coluna), pois, como afirmamos acima, a revista demorava em média um ano para ser produzida. No entanto, os dados da tabela do relatório foram desdobrados nos da revista. Verifica-se uma preocupação em aprimorar os dados do relatório dividindo-os, por exemplo, no número de escolas por série e não apenas em divulgar o número total de escolas. Além disso, o uso das tabelas tinha finalidades diferentes em cada tipo de material. No relatório, a tabela era utilizada para registrar o número de unidades escolares de $1^{\circ} \mathrm{grau}$ em bairros pobres e periféricos. $\mathrm{Na}$ 
revista, serviriam para confirmar o ritmo de integração das escolas de $1^{\circ} \mathrm{grau}$, ou melhor, quantas escolas tinham classes de primeira a oitava séries.

Todas as instituições necessitam de dados quantitativos para uma visão mais ampla de seu funcionamento e organização, todavia, o ensino municipal os utilizava para confirmar seu crescimento e expansão o que, por sua vez, deveria informar sobre o êxito de sua administração. A revista Escola Municipal era a vitrine do modelo escolar paulistano de gestão para o ensinar. Portanto, não é surpresa que os dados fossem reformados dos relatórios de gestão para os da revista e, nela, omitissem informações que comprometessem ou acrescentassem outras que reforçassem sua suposta objetividade.

Para Natália de Lacerda Gil (2008), que trabalhou com a produção das estatísticas escolares,

investigar a imagem de escola expressa nas estatísticas educacionais obriga a assumir que estas não se constituem um instrumento objetivo de apreensão da realidade. Permitem ver, no entanto, a disputa de representações sobre a instituição escolar travada entre diferentes segmentos da elite intelectual e política. É preciso colocar em questão até mesmo a existência de uma realidade externa aos recursos que permitem percebê-la e a ela se referir, cuja melhor compreensão dependeria do aperfeiçoamento dos recursos capazes de Ihe 'traduzir', 'mostrar', 'revelar' a imagem. Assumindo-se a representação do real como elemento intrínseco à sua construção, as estatísticas são tomadas, não como ferramenta a permitir sua adequada visualização, mas sim como elemento participante de sua composição. (p. 357)

Portanto, o leitor da revista deveria consumir tais dados não como um pesquisador, mas como aquele que aceita sua transparência de modo a melhor administrar o planejamento escolar. Seu público não era apenas os dos diretores de escolas, mas de professores e funcionários, que deveriam medir o grau de integração de suas escolas, ou seja, do cumprimento do currículo da escola integrada de oito anos. Supunha-se que a partir daqueles dados seria possível aprimorar o ensino municipal dentro e fora de sala de aula como um professor-administrador.

Um último exemplo demonstra a dificuldades de se libertar de um modelo de gestão administrativa racional e burocrática que se estruturou nos anos da ditadura militar para um novo discurso democrático, que pretendia criticar o autoritarismo nas escolas municipais. Tais discussões e críticas marcam a última fase da revista que ainda vivia no período de rescaldo da ditadura militar.

Na revista de número 12, de 1984, a chamada de capa da matéria Não confunda autoritarismo com autoridade na escola (Escola Municipal, 1984, n.12, capa) diferia do título do seu conteúdo interno: Debate autoridade autoritarismo na escola (p. 28). A chamada da capa era mais incisiva e colocava os próprios limites do debate que viria a seguir. A imagem que abre a matéria é uma charge do cartunista Henfil criticando o autoritarismo na escola, que se contrapõe, na página dupla, a uma fotografia de uma sala de aula com alunos enfileirados em carteiras diante de um professor sentado em uma cadeira frente a uma mesa em degrau mais alto, numa espécie de púlpito. Mais do que 
duas épocas distintas, a contraposição das imagens sugeria um tempo dentro do outro: o autoritarismo controlador do presente e autoridade disciplinar na sala de aula.

O editorial da matéria convidava o leitor a ampliar o debate e perguntava: "como romper este círculo vicioso?", isto é, como "discernir os limites entre o legítimo exercício da autoridade, garantindo que os interesses dos alunos sejam atendidos [...] e o abuso da autoridade ou autoritarismo" (Escola Municipal, 1984, p. 28-29). Obviamente, a discussão extrapolava a sala de aula e também se dirigia para que forma de administração adotar.

O debate era uma transcrição de uma reunião entre Teresa Roserley $\mathrm{N}$. da Silva, chefe de gabinete da SME, Vera Lucia Wey, delegada de Ensino da Drem-4, Celso Ferretti, orientador educacional, Célia Trevisan, professora de nível 2, e Yeda de Andrade e Silva, delegada de ensino da Drem-5. De início, chama atenção haver apenas uma professora na discussão. Os outros integrantes do debate pertenciam à burocracia da administração do ensino municipal, assemelhando-se mais a uma reunião tradicional do que a um fórum. Ainda que a publicação representasse um debate, o professoradministrador ainda assistia tudo de fora, somente com um representante da categoria. Reproduzo um trecho significativo:

Yeda: Quando eu separei a questão da administração da educação entre burocracia estatal, a sociedade ou comunidade e pensando no exemplo específico da grade curricular, o que eu imagino, por exemplo, é que uma comunidade pode ter interesses específicos que ela resolva colocar no seu projeto educacional e que possam não ser necessariamente os interesses da sociedade como um todo.

Vera: Aí você teria uma certa autonomia dentro do que está sendo projetado naquela comunidade, em função dos seus interesses específicos, sem que isso fosse imposto para outras escolas de outras comunidades.

Celso: Permanece a questão colocada. Vamos supor que no limite, cada escola ou cada região tivesse sua grade curricular. Nesse caso teríamos um tal esfacelamento da ação educativa que o Estado perderia o controle sobre ela.

Rose: É um retrocesso pensar em omissão do Estado. Quer dizer, quando temos a passagem da sociedade feudal para a sociedade estatutária, em que o Estado está presente, deixamos de atender o interesse pequeno nas comunidades, para pensar no interesse coletivo. Isto é um consenso na sociedade estatutária: a presença do estado é um avanço. Se esse Estado em alguns momentos exerce um papel mais ou menos autoritário, se ele extravasa a sua autoridade em relação a uma proposta mais ou menos liberal, podemos analisar como é que chegou a isto. Numa sociedade gigantesca, urbana e industrial, você tem que encontrar algumas diretrizes comuns, sejam elas em educação, saúde ou outras áreas quaisquer.

Celso: Uma coisa é traçar as diretrizes maiores e outra é a questão do centralismo. Se você se envolve numa ação centralizada, burocrática e hierarquizada demais, na verdade você facilita as condições do exercício autoritário. O Governo assumiu uma máquina centralizada e está atuando dentro dessa máquina. É difícil quebrar e superar os mecanismos montados. As condições para que o processo democrático comece a existir têm que ser criadas. E aí entra também a questão dos limites, isto é, quando você deve dar uma mão forte porque as coisas não andam e quando você deve soltar. É o limite entre autoritarismo e a autoridade democrática. A administração tem que ter clara percepção de que esses limites são fluidos e de que esse risco tem que ser corrido. É preciso 
permitir uma certa abertura até para que o erro ocorra, desde que esse erro não seja tão grande, que subverta o objetivo fundamental. Se você quiser amarrar tudo tão bem, que não possa haver erros, acabou. Aí sim, você corre o risco de fazer a fala democrática e a prática autoritária.

Vera: Nós temos que garantir as diretrizes estabelecidas e ao mesmo tempo abrir a discussão, buscando uma participação cada vez maior das escolas.

Yeda: É um jogo em que se tem um risco a correr. A administração tem que manter certos controles senão perde sua proposta, mas se amarrar demais também perde.

Celso: Esse andar no arame é a arte que a administração vai ter que praticar na área financeira, na área administrativa, na área pedagógica. Você tem que soltar e amarrar, soltar e amarrar. (Escola Municipal, 1984, p. 32)

O debate sintetizava os conflitos vividos pelo ensino municipal desde o momento que a revista Escola Municipal passou acompanhar, instaurar e divulgar o modelo escolar paulistano de gestão para o ensinar em 1968. Apesar das críticas ao centralismo administrativo, ele ainda prevalecia como sinônimo de estabilidade do sistema municipal de ensino. Tal centralismo era uma forma de traduzir o controle administrativo implantado ao mesmo tempo em que se buscava se diferenciar dele ao justificá-lo. De fato, naquele momento, não havia propostas de descentralização administrativa, as quais só seriam amparadas legalmente, ainda que de maneira formal, com a Lei de Diretrizes e Bases da Educação Nacional de 1996, confirmando a hipótese da prevalência da desconcentração de poderes (Lattouf, 2001).

O debate girava em torno de dois eixos: como justificar que um governo que se pretendia democrático, orientado pelo PMDB, não conseguisse se desvencilhar de práticas administrativas provenientes do auge do regime militar? $\mathrm{E}$ como a oposição tomando o governo como autoridade não se confundisse com a imagem autoritária de um governo militar? Tentava-se justificar mais a permanência de um modelo de gestão em que prevalecia o controle do que defender a autoridade em sala de aula ou dirimir a confusão com o autoritarismo.

O impasse estava armado, pois a gestão para o ensinar não se amoldava a um autoritarismo disciplinador, traduzido por centralismo, que se tornou arma de combate contra o regime naquele período. Era difícil admitir que a administração municipal, durante o regime militar, já havia superado a tensão entre autoritarismo e autoridade, mas que era alardeado como um novo debate democrático. No setor educativo criou um modelo mais aberto, flexível ou dúctil de gestão administrativa que garantia o seu funcionamento e controle, ainda que as fragilidades aparecessem no seu movimento de soltar e amarrar reformistas, mas que não sustentavam críticas rápido-fáceis em nome da ditadura militar.

O esquecimento da história da escola e do ensino municipal de São Paulo na história da educação revela o quão recente e vivo o período permanece em práticas administrativas educacionais. Esse andar no arame como arte de administrar em sociedades de controle. 


\section{Referências}

ABREU, Ivanir Reis Neves. Convênio escolar: utopia construída. São Paulo: USP, 2007. 336f. Dissertação (mestrado em Arquitetura e Urbanismo). Faculdade de Arquitetura e Urbanismo, Universidade de São Paulo.

CARVALHO, Marta Maria Chagas de. Pedagogia moderna, pedagogia da escola nova e modelo escolar paulista. In: CARVALHO, Marta Maria Chagas de; PINTASSILGO, Joaquim (orgs.). Modelos culturais, saberes pedagógicos, instituições educacionais: Portugal e Brasil, histórias conectadas. São Paulo: USP/Fapesp, 2011, p. 185-212.

CHAMOUN, Sidoni. Entrevista a Alexandre Pianelli Godoy e Helenice Ciampi. 6 fev. 2012.

CUNHA, Luiz Antônio. O ensino profissional na irradiação do industrialismo. São Paulo: Unesp; Brasília: Flacso, 2005.

DE CERTEAU, Michel. A invenção do cotidiano 1: artes de fazer. Petrópolis: Vozes, 1996.

DE CERTEAU, Michel. A escrita da história. Rio de Janeiro: Forense Universitária, 2000.

DE CERTEAU, Michel. História e psicanálise: entre ciência e ficção. Belo Horizonte: Autêntica, 2011.

DELEUZE, Gilles. Conversações, 1972-1990. Rio de janeiro: 34, 1992.

DIÁRIO OFICIAL DO MUNICÍPIO DE SÃO PAULO. (18/03/1980, p. 31).

DIAS, Ethel Cristina Fernandes de Souza. Entrevista a Alexandre Pianelli Godoy e Helenice Ciampi. 13 fev. 2012.

GIL, Natália de Lacerda. A produção dos números escolares (1871-1931): contribuições para uma abordagem crítica das fontes estatísticas em História da Educação. Revista Brasileira de História, v. 29, n. 58, 2009, p. 241-358.

GOODSON, Ivor F. Currículo: teoria e história. Petrópolis: Vozes, 1995.

LATOUFF, Marlene de Paulo. As origens do ensino municipal de São Paulo e a participação feminina. São Paulo: USP, 2001. 187f. Dissertação (mestrado em Educação). Faculdade de Educação, Universidade de São Paulo.

NORA, Pierre. Entre memória e história: a problemática dos lugares. Revista Projeto História. São Paulo: PUCSP, n. 10, 1993, p. 7-27.

PASTA DO. 2/Pj. 003/83

RELATÓRIOS DE GESTÃO MUNICIPAL. (1971, 1976, 1977, 1978, 1979/82, 1981 , 1983/85).

REVISTA ESCOLA MUNICIPAL. (1968-1985).

SPOSITO, Marilia Pontes. Demandas populares por escola na relação com o mundo do trabalho. In: PRADO, Maria Ligia Coelho, VIDAL, Diana Gonçalves (org.). À margem dos 500 anos: reflexões irreverentes. São Paulo: Edusp, 2002, p. 99-109.

TOLEDO, Maria Rita de Almeida; REVAH, Daniel. O regime militar na (des)memória da Editora Abril: A Revista Escola e a difusão da lei 5.692/71. História da Educação, Porto Alegre: Asphe, v. 15, n. 33, 2011, p. 137-161.

VESENTINI, Carlos Alberto. A teia do fato: uma proposta de estudo sobre a memória histórica. São Paulo: Hucitec, 1997.

VIRILIO, Paul. Velocidade e política. São Paulo: Estação Liberdade, 1996. 
ALEXANDRE PIANELLI GODOY é professor adjunto do Departamento de História da Universidade Federal de São Paulo, campus Guarulhos. Doutor em História Social pela PUCSP, desenvolve pesquisa sobre a história do ensino municipal paulistano e suas relações com os impressos, arquitetura e currículos escolares no período da ditadura militar.

Endereço: Rua Voluntários da Pátria, 2695/21 - 02401-100 - São Paulo - SP - Brasil. E-mail: le.godoy@terra.com.br.

Recebido em 21 de junho de 2012.

Aprovado em 12 de outubro de 2012. 